\title{
Pemikiran Hukum Islam Tentang Fiqh $\mathrm{Al}$ - Awlawiyyat
}

\author{
Oleh: \\ Muhammad Hatta Diponegoro ${ }^{1}$ \\ Email: fitria.hatta@gmail.com
}

\begin{abstract}
Basically, Islamic legal thought is very demanding a person's understanding of the Qur'an and alhadith, in the hope of formation of the application in line with the rules of Shari'a. Therefore, an in-depth understanding of an Islamic legal thought is necessary. Among the understanding is what is called the figh alawlawiyyat. Figh priority or figh in the priority scale balance is intended is a complex understanding of the study of Islamic law in a more proportional, with the intent and purpose for a mukallaf able to provide value for a practice in accordance with the views of Islamic Shari'a,because the majority of Muslims are considered not able to put the values of worship and practice in accordance with the guidance of the Shari'a, then there is confusion that is happening to the Muslims. Confusion in determining this priority scale will be very dangerous if it continues to be left, then efforts to stem danger and clarify the problem need to be realized.Islamic Shari'ah has placed certain values and stages for each act in accordance with its influence in the soul and life.as Islam also sets a certain level for things that are prohibited in accordance with its harm and badness for humans. The tendency to put forward something that is sunnah from the obligatory or overriding the more important of something important, it would discredit the value and purpose of the Shari'a.
\end{abstract}

Keywords: thought, Islamic law, figh priority

\section{Pendahuluan}

Hukum Islam yang bersumber dari al-Qur'an dan al-Hadits merupakan ajaran terakhir yang diwahyukan oleh Allah Swt kepada Rasulullah Muhammad Saw. ${ }^{2}$ Oleh karena itu, sejak periode awal sejarah

\footnotetext{
${ }^{1}$ Dosen Program Studi Hukum Pidana Islam STAI Syaichona Moh. Cholil Bangkalan Madura.

2 Abd. Karim Zaidan, Majmu'at Buhuts Fiqhiyyah ( Baghdad: Maktabah al-Quds, 1986 ), 11. Bahkan menurut Joseph Schacht, ia berpandangan bahwa hukum Islam adalah sejumlah aturan agama yang mengatur kehidupan kaum Muslim dalam berbagai aspeknya, baik yang bersifat individu maupun kolektif. Menurutnya para penganut barat menilai
} 
perkembangan Islam, perilaku kehidupan kaum muslim dalam keseluruhan aspeknya telah diatur oleh hukum Islam. Dalam perkembangannya hukum Islam selalu diupayakan berdasarkan al-Qur'an, sementara aplikasi sebagian besarnya telah diterangkan operasionalnya di dalam Hadits Rasulullah Saw.

Dalam konteks pemikiran hukum Islam, pemahaman yang menjelaskan tentang suatu amalan yang rajih dari amalan yang lain, yang sahih dari yang tidak sahih, yang diterima dari yang tertolak, yang sunnah dari yang tidak disunnahkan, serta memberikan nilai bagi setiap amalan sesuai dengan pandangan syariat, sering kali terlupakan. Karenanya, permasalahan ini cukup menyisakan sejumlah persoalan mengingat pemahaman dalam unsur di atas acapkali menimbulkan kesalahfahaman dan kekaburan akan kajian pokok syariat ini.

Di negara yang notabene dianggap sebagai negara yang berpopulasi penduduk muslim terbesar, dalam berbagai fenomena kehidupan, adanya kecenderungan mendahulukan hal-hal yang terkait dengan pendidikan dan ilmu pengetahuan misalnya, peningkatan pada bidang fisik selalu mendapat perhatian lebih daripada peningkatan dalam bidang intelektual, bahkan pada gilirannya dapat melihat dengan sangat jelas saat ini banyak orang yang lebih mementingkan fisik daripada kekuatan ruhani.

Neraca skala prioritas inilah yang kemudian oleh Syeikh Muhammad Yusuf al-Qardhawi disebut sebagai pemikiran hukum Islam figh alawlawiyyat. Hal yang dimaksud adalah suatu pemahaman yang kompleks terhadap kajian hukum Islam baik dalam masalah-masalah ibadah maupun muamalah secara lebih proporsional, dengan maksud dan tujuan agar seseorang mampu secara proporsional menentukan nilai terbaik dalam suatu amalan sesuai dalam pandangan hukum Islam, sebab masih terlalu banyak umat muslim saat ini yang belum mampu menempatkan nilai-nilai itu sehingga terjadilah ketimpangan, sesuatu yang wajib dianggapnya sunah dan yang sunah dianggapnya wajib dan seterusnya.

bahwa mustahil memahami Islam tanpa adanya pemahaman terhadap hukum Islam. Lihat Joseph Schacht, An Introduction to Islamic Law ( London : Oxford at The Clarendom Press, 1971 ), 1. 
Kelemahan ini tidak saja terjadi pada kalangan awam atau mereka yang menjaga jarak dengan kalangan orientalis, sekularis, dan liberalis, tetapi juga terjadi pada kalangan "terdidik" dan bahkan tokoh kegamaan sekalipun. Tentu saja, hal ini disebabkan karena kurang adanya pemahaman dan pendalaman fikih secara proporsional berdasarkan petunjuk pengetahuan yang benar. Ada indikasi, mereka memberikan status hukum terhadap suatu amalan tertentu tidak sesuai dengan yang dikehendaki oleh syariat, sehingga mereka cenderung menilai amal secara tidak proporsional. Suatu amalan terkadang menjadi utama dalam suatu kondisi, dan menjadi tidak utama dalam kondisi yang lain, atau rajih pada suatu kondisi dan marjuh pada kondisi yang lain, akan tetapi, karena keterbatasan ilmu dan pemahaman, mereka tidak lagi membedakan antara dua waktu yang berbeda, atau antara dua kondisi yang tidak sama.

Kerancuan besar ini sungguh telah menimpa umat Islam dewasa ini, sehingga persoalan-persoalan besar dianggap kecil dan persoalanpersoalan kecil dianggapnya besar. Hal-hal yang sebenarnya ringan, kemudian dibesar-besarkan, sementara yang urgen justru mereka anggap sesuatu yang ringan. Sesuatu yang fardu diabaikan, sedangkan yang sunah dilestarikan. Sampai pada akhirnya masalah-masalah khilafiyah selalu menjadi perbincangan yang hangat, sedangkan apa yang sudah disepakati, kurang menjadi perhatian. Ini semua membuat umat ini membutuhkan figh al-Awlawiyyat dalam upaya mencari sejatinya nilai hukum Islam yang sesungguhnya.

\section{Pandangan Ulama Tentang Fiqh al-Awlawiyyat}

Banyak ulama yang menaruh perhatian terhadap persoalan ini. Salah satu diantaranya adalah al-Imam al-Ghazali, menurut al-Qardhawi, umumnya mereka mengkritik kondisi masyarakat muslim yang tidak terlalu memperhatikan figh al-Awlawiyyat dan kurang memahami urgensinya. Al-Imam al-Ghazali menjelaskan, sebagaimana dikutip oleh alQardhawi, diantara mereka adalah para ilmuwan, ahli tasawuf, ahli ibadah, para hartawan dan selebihnya adalah orang-orang awam. Dalam hal ini, al-Qardhawi menjelaskan 2 contoh kritik al-Imam al-Ghazali yang 
kuat, mendalam dan bijaksana. Diharapkan dapat diketahui kadar pemahaman keagamaannya. ${ }^{3}$

Contoh pertama, disebutkan bahwa di antara sekelompok masyarakat muslim terdapat orang-orang yang melalaikan ibadah fardu dan menyibukkan diri pada ibadah fadail dan nawafil. Terlihat di antara mereka merasa bangga dengan yang sudah mereka lakukan dari shalat dhuha, shalat malam, sementara mereka tidak merasa mendapatkan ketenangan hati saat melakukan shalat fardu, terlebih mereka tidak berusaha untuk menunaikannnya di awal waktu. Mereka mengabaikan ketertiban urutan dalam masalah kebaikan, bahkan termasuk keburukan. Banyak hal yang tidak diketahui dan tidak pula disadari bahwa mereka telah mendahulukan sebagian ketaatan atas sebagian yang lain sesuai dengan koridor syariat. Sebagai contoh, bila ada seseorang yang hartanya belum cukup untuk melakukan dua hal sekaligus, tetapi hanya cukup untuk salah satunya, manakah yang harus ia prioritaskan, untuk menafkahi kedua orang tua yang lebih membutuhkan ataukah untuk menunaikan ibadah haji. Bila ia lebih memilih untuk menunaikan ibadah haji, maka ia tertipu, padahal ia seharusnya lebih mendahulukan hak kedua orang tuanya ketimbang menunaikan ibadah haji. Ini berarti mendahulukan fardu yang lebih penting daripada fardu yang di bawahnya.

Para dai kebangkitan Islam sangat membutuhkan kejelian dan ketajaman berpikir al-Imam al-Ghazali. Al-Qardhawi memberikan komentar tentang pribadi al-Imam al-Ghazali:

$$
\begin{aligned}
& \text { وطالما دعوت منذ مدة شباب الصحوة و الجماعات الدينية إلى ما سميته "فقه مراتب } \\
& \text { الأعمال" و إعطاء كل عمل "سعره" الشرعي و مكانه في سلم المأمورات و المنهيات, ولم } \\
& \text { أكن قرأت ما كتبه الغزالي هنا بهذا العمق و الوضوح, وعبر عنه بهذه الكلمة الناصعة : "ترك } \\
& \text { الترتيب بين الخيرات من جملة الشرور" }
\end{aligned}
$$

${ }^{3}$ al-Qardhawi, Awlawiyyat al-Harakah al-Islamiyyah, 38-39. 
Sepanjang saya menyerukan lahirnya kebangkitan organisasiorganisasi keagamaan dengan memberikan nilai kesyariatan pada setiap amal termasuk posisinya dalam jenjang perintah dan larangan, saya belum pernah membaca seperti yang ditulis sang Imam demikian mendalam dan mengungkapkan kalimat yang amat bermakna, "meninggalkan urutan antara kebaikan-kebaikan adalah jenis kejahatan"4

Contoh kedua, adalah kelompok hartawan, di antara mereka berusaha keras untuk membangun masjid, pesantren, madrasah dan bangunanbangunan yang dapat dilihat orang banyak. Mereka ini kemudian menuliskan nama-namanya pada bangunan-bangunan tersebut agar dapat diabadikan dan tetap dapat dikenang pada generasi sesudahnya. Mereka mengira bahwa dengan upaya seperti itu akan mendapatkan ampunan Allah, padahal mereka tertipu dengan dua sebab.

Pertama, selama ini mereka memperoleh harta dari cara yang dzalim dan terlarang. Jika dalam memperolehnya mereka telah durhaka kepada Allah, maka mereka wajib bertaubat dan kembali kepada-Nya, lalu mengembalikan harta-harta itu kepada pemiliknya, baik dalam bentuk benda atau dalam bentuk penggantinya bagi yang tidak mampu melakukan yang pertama. Bila para pemiliknya telah tiada, maka hartaharta itu harus diberikan kepada ahli warisnya. Bila para ahli waris pemilik benda itu telah tiada pula, maka ia wajib mengeluarkannya untuk kepentingan yang lebih bermanfaat dan yang terpenting adalah mengalokasikannya untuk orang-orang miskin, akan tetapi mereka tidak melakukan hal itu karena takut yang mereka lakukan tidak diketahui orang banyak. Mereka lebih memilih mendirikan bangunan-bangunan dengan tujuan riya' dan memperoleh pujian. Mereka berusaha keras untuk menjadikannya sebagai bangunan monumental, termasuk namanya yang terpampang di dalamnya.

Kedua, mereka mengira diri mereka ikhlas, karena infak yang mereka berikan untuk pembangunan dengan tujuan baik, namun sayang, apabila namanya tidak tertulis pada bangunan itu, mereka tidak bersedia menginfakkan hartanya, padahal Allah maha mengetahuinya, baik ditulis

${ }^{4}$ Al-Qardhawi, al-Imam al-Ghazali bayna Mādihīhi wa Naqidihi (Kairo: Dar alwafā', 1995), 87-90. 
namanya ataupun tidak. Kalau tidak karena ingin dilihat manusia tentu dia tidakakan melakukan hal seperti itu. ${ }^{5}$

Ada satu kelompok dari kalangan hartawan yang bekerja untuk menjaga harta yang dimilikinya dan menahannya dengan kekikiran, lalu mereka sibuk dalam ibadah-ibadah fisik yang sekiranya tidak membutuhkan pengeluaran harta, seperti puasa siang hari, shalat malam, atau menghatamkan al-Qur'an. Dalam konteks ini, Abdullah Ibn Mas'ud salah satu sahabat Nabi Saw pernah berkata bahwa di akhir zaman nanti banyak orang menunaikan ibadah haji tanpa sebab, perjalanan mereka mudah, rezeki mereka lapang, namun mereka kembali dengan hampa dan dengan hal-hal yang negatif. Unta salah seorang dari mereka melaju di tengah padang pasir dan gurun yang tandus, sementara tetangganya dililit kelaparan. Seolah-olah Ibn Mas'ud melihat zaman kita sekarang dan menjelaskan apa yang sebenarnya terjadi.

Ulama Hasan al-Banna memberikan pemikirannya terhadap Figh alAwlawiyyat terutama pada upaya meluruskan pemahaman Islam bagi kaum muslim dan mengembalikan ajaran Islam yang terhapus melalui tangan-tangan para westernis dan sekularis. Mereka menghendaki Islam sebagai akidah tanpa syariat, negara tanpa agama, kebenaran tanpa kekuatan, dan perdamaian tanpa jihad. Sementara itu, al-Banna berharap Islam sebagai yang dikehendaki Allah yaitu akidah dan syariat, negara dan agama, kebenaran dan kekuatan, perdamaian dan jihad, mushaf dan pedang.

Ia berusaha secara optimal untuk menjelaskan kepada manusia bahwa politik merupakan bagian dari Islam dan kemerdekaan merupakan suatu kewajiban. Ia mengorientasikan perhatian dan kesungguhannya untuk membentuk generasi muslim baru yang bertujuan rabbani dengan ilmu dan takwa, berpandangan Islami dan meneladani Nabi Saw. Generasi yang memahami Islam secara benar dan cermat, menjalankan Islam dengan sebaik-baiknya, dan kemudian bekerja untuk mengarahkan kebangkitan Islam. Untuk tujuan ini, menurut al-Qardhawi, ia ingin mempersatukan dan menginginkan adanya integrasi, karenanya ia tidak mengangkat topik-

${ }^{5}$ Al-Qardhawi, Fi fiqh al-Awlawiyyat, 256. 
topik yang memecah belah umat Islam serta melepaskan sekat-sekat bagi kelompok-kelompok tertentu. ${ }^{6}$

Ulama Abu al-A'la al-Maududi memberikan pemahaman tentang Figh al-Awlawiyyat berupa perang melawan "jahiliyah modern", mengembalikan manusia pada agama dan ibadah dalam pengertian yang komprehensif, tunduk pada hukum-hukum Allah dan menolak hukumhukum makhluk, apapun kedudukan dan tugasnya baik para pemikir maupun para pemimpin politik. Membangun kebudayaan Islam spektakuler dengan menolak pemikiran barat tentang peradaban, ekonomi, politik, kehidupan pribadi, keluarga dan masyarakat. Ia juga mengambil suatu metode khusus dalam tranformasi, untuk itu kemudian ia menulis banyak buku dan risalah. Buku-buku itu mengungkapkan falsafah dirinya tentang dakwah Islam dan pembaruannya, dan jamaahnya menghimpun dana serta menyebarluaskannya.

Ulama Sayyid Qutb,7 juga memberikan gambaran pemahaman tentang Figh al-Awlawiyyat pada bidang akidah sebelum hukum, ia melakukan pelurusan konsepsi akidah bagi Islam, sebab tidaklah mungkin mengadakan pelurusan suatu amal yang muncul dari konsepsi yang salah atau rusak, karena ia menolak konsep "jahiliyah modern” dalam berbagai aspeknya, baik dalam konteks akidah, pemikiran, tingkah laku, dalam kehidupan pribadi, keluarga atau bahkan masyarakat. Ia beranggapan bahwa seluruh masyarakat yang di seluruh penjuru dunia ini, termasuk dunia Islam, merupakan masyarakat jahiliyah, bila masyarakat tersebut menolak hukum Allah, yaitu pemerintahan yang mengembalikan formasi syariat dan undang-undang serta meletakkan nilai-nilai dan pertimbangan-

${ }^{6}$ Ibid., 275-276

${ }^{7}$ Sayyid Qutb adalah salah satu tokoh Ikhwan al-Muslimin, seorang ulama yang dilahirkan di kota Asyut, Mesir pada tahun 1906. Ia mula-mula dididik dilingkungan keluarganya didesa dan sudah hafal al-Qur'an sejak masih berusia anak-anak. Pernah bekerja sebagai pengawas sekolah di Departemen Pendidikan. Dalam rangka memperdalam pengetahuannya dalam bidang pendidikan, ia mendapat tugas belajar ke Amerika Serikat selama dua tahun. Ia termasuk salah satu petinggi Ikhwan al-Muslimin yang ditahan, setelah organisasi itu dilarang di Mesir oleh presiden Gamal Abd. Naser dengan tuduhan berserikat untuk menjatuhkan pemerintahan pada tanggal 29 agustus 1966. Bersama dua orang temannya, ia menjalani hukuman mati. Lihat Ensiklopedi Islam, (Jakarta: Ichtiar Baru Van Hoeve, 1993), 470. 
pertimbangan juga pengawasan dan pemahamannya merupakan asas bagi masyarakat dan kehidupannya.

Di dalam kitab tafsirnya, Sayyid al-Qutb memberikan keterangan mengenai firman Allah:

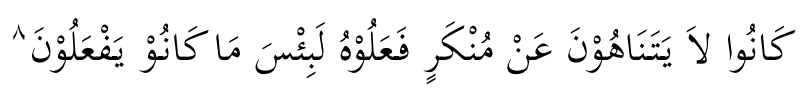

"Mereka satu sama lain selalu tidak melarang perbuatan munkar yang mereka perbuat. Sesungguhnya amat buruklah apa yang mereka perbuat".

Ia menjelaskan bahwa sesungguhnya kesungguhan yang kuat dan pengorbanan yang mulia harus difokuskan pertama-tama untuk menegakkan masyarakat yang berdiri d iatas manhaj Allah sebelum mengerahkan pengorbanan dan kemampuan untuk reformasi secara parsial melalui jalur amar makruf nahi munkar. Sangat tidak bermakna upaya parsial dijalankan ketika tirani jahiliyah berkembang pesat di tengah-tengah masyarakat, ketika masyarakat menjalankan hukum yang bukan hukum Allah, maka seharusnya upaya dapat dilakukan dari yang paling dasar dan akan tumbuh melalui akar-akarnya. Dan ketika kekuasaan sudah cukup eksis, maka amar makruf nahi munkar merupakan sesuatu yang mengakses ke bagian dasar.

Sesungguhnya setiap teks baik al-Qur'an maupun al-Hadits yang membahas amar makruf nahi munkar selalu membicarakan tentang kewajiban setiap individu muslim terhadap masyarakat Islam. Masyarakat jahiliyah yang tidak berhukum berdasarkan hukum Allah, maka yang terjadi adalah kemungkaran, menolak ketuhanan Allah dengan cara menolak hukum dan syariat-Nya dalam kehidupan. Kemungkaran besar dan esensial ini merupakan sesuatu yang harus dihindari sebelum seseorang memasuki kemungkaran yang lebih parsial. ${ }^{9}$

Apa perlunya melarang seseorang untuk tidak memakan sesuatu yang haram, misalnya, bila sebuah masyarakat seluruh sistem perekonomiannya

\footnotetext{
'al-Qur'an, 5: 79

${ }^{99}$ Sayyid Qutb, fi Dzilal al-Qur'an (Kairo: Dar al-Syuruq, 1998), 947-950.
} 
sangat dimungkinkan seluruh hartanya haram, sehingga tidak seorangpun yang makan dari harta yang halal. Apa gunanya melarang seseorang dari perbuatan keji, kalau misalnya hukum dan peraturannya tidak menganggap perzinaan sebagai perbuatan kriminal. Apa manfaatnya melarang seseorang yang sedang mabuk dalam suatu kondisi masyarakat yang undang-undangnya masih memperkenankan produksi minumminuman keras, mendistribusi bahkan mengkonsumsinya, selain tidak adanya kepastian hukum, hal ini juga akan mengakibatkan terganggunya ketertiban umum. ${ }^{10}$

Diantara ulama yang cukup concern terhadap figh al-awlawiyyat secara teoritis dan praktis adalah Muhammad al-Ghazali. Perhatian besar ini tampak pada karya-karyanya yang ditulis akhir-akhir ini. Terdapat kutipan teks Muhammad al-Ghazali yang menjelaskan tingkat pemahaman dan kepekaannya terhadap figh al-awlawiyyat, serta membangun perspektif komprehensif yang dapat menilai sesuatu secara berimbang dan proporsional. Menurutnya, dalam ritual ibadah shalat misalnya, dapat melahirkan ketertiban, kedisiplinan dan kebersihan, sementara mereka hidup secara anarkis dan acak-acakan. Juga dalam ibadah haji misalnya, ia merupakan perjalanan seumur hdup yang bertujuan untuk mendayagunakan hati dan anggota badan dengan ketenangan dan kasih sayang. Namun justru pada saat pelaksanaan manasik atau bahkan setelahnya masih saja keras, kasar, tanpa ada rasa kasih dan sayang. Seakan-akan Islam hanya menuai duri dari orang-orang yang sedikit pemahamannya terhadap ilmu fikih. Banyak kegiatan fisik yang dilakukan dengan akal yang dangkal, lalu beramal buruk dan tidak berbuat baik.

Studi tentang figh al-awlawiyyat ini merupakan penyempurnaan dan perincian dari apa yang pernah dianjurkan oleh para ulama. Dengan demikian diharapkan dari kajian ini dapat mengisi celah kosong dalam pemikiran hukum Islam kontemporer.

${ }^{10}$ Ibid, 150-151. 


\section{Yusuf al-Qardhawi dan Figh al-Awlawiyyat}

Termasuk ulama yang juga concern terhadap figh al-awlawiyyat adalah yusuf al-Qardhawi, ${ }^{11}$ Ada beberapa bentuk figh al-awlawiyyat dalam pemikiran al-Qardhawi, diantaranya adalah:

1. Al-Awlawiyyat terhadap tujuan syariat

Di antara materi kajian ilmu fikih adalah mendalami dan memahami dengan baik tujuan syariat atau mengkorelasikan antara satu bagian nash ke bagian nash yang lain, baik melalui al-Qur'an maupun alHadits. Tidak berhenti pada sisi luar nash serta tidak terikat pada tekstualnya saja, tapi juga kontekstual. Dalam konteks tujuan syariat ini, lebih lanjut al-Qardhawi memberikan komentar bahwa saat ini banyak sisi kelemahan bagi mereka yang menyibukkan dalam ilmu agama yang bersifat lahiriah, bukan pada rahasia dan tujuan ilmu. Mereka menjelaskan syariat dan hukum-hukum Allah secara parsial, tidak komprehensif dan tidak mengaitkannya dengan 'illat al-hukm. Bila hal ini terjadi, maka yang terlihat bagi syariat Islam seolah tidak merealisasikan kemaslahatan manusia. ${ }^{12}$

Kelemahan-kelemahan ini bagi al-Qardhawi terletak pada pemahaman mereka yang melepaskan keterkaitan antara satu teks dengan teks yang lain. Kebanyakan pemahaman teks secara lahiriah ini akan melahirkan kesimpulan hukum yang cenderung mempersempit apa yang sebernarnya diperluas oleh Allah dan mempersulit apa yang sebenarnya dipermudah oleh Allah. Serta membekukan apa yang sebenarnya dapat dikembangkan dan membatasi apa yang sebenarnya dapat diperbaharui.

${ }^{11}$ Nama lengkapnya adalah Yusuf Abdullah al-Qardhawi, terlahir dalam keadaan yatim didesa Gharbiyyah, desa ini sekarang terkenal dengan nama Tanta. Ia dilahirkan pada tanggal 9 September 1926. Pada saat ayahnya meninggal, ia baru berusia dua tahun, oleh sebab itu, sejak kecil ia sdh diasuh pamannya. Pamannya inilah yang selalu setia mengantarkan al-Qardhawi kecil untuk selalu belajar mengaji. Di daerahnya, al-Qardhawi dikenal sebagai anak yang sangat cerdas, begitu cerdasnya, hingga ia mampu menghafal alQur'an sebelum berusia 10 tahun, bahkan ia mampu menguasai hokum-hukum tajwidnya denagn sangat baik.

${ }^{12}$ Al-Qardhawi, Fi Fiqh al-Awlawiyyat, 73-74. 
2. Al-Awlawiyyat terhadap jalan kemuduhan

Dalam kajian hukum Islam, prinsip mendahulukan usaha untuk lebih memudahkan selalu harus lebih diupayakan. Al-Qardhawi dalam kebijakannya dalam suatu kesempatan mengatakan, bahwa bila ia menghadapi dua pendapat yang hampir bersamaan dalam syariat, yang satu lebih berat dan yang lain lebih ringan untuk diterapkan, maka ia akan memberikan fatwa kepada masyarakat dengan pendapat yang lebih ringan daripada yang lebih memberatkan. Al-Qardhawi menjelaskan dasar pemikirannya adalah petunjuk Nabi Saw, saya tidak memilih diantara dua hal kecuali yang lebih ringan. Nabi Saw memerintahkan kepada para imam dalam shalat berjamaah agar meringankan shalatnya, sebab diantara makmum terdapat yang lemah, tua, atau mempunyai keperluan tertentu. ${ }^{13}$

Nabi Muhammad Saw paling keras menentang sebagian orang yang suka memberat-beratkan terhadap suatu kelompok, walaupun pemberatan itu sekedar untuk pribadi. Hal ini dapat kita temukan pada sikap Nabi Saw, ketika itu menolak pandangan tiga orang yang datang kepadanya dengan menunjukkan ibadah-ibadah yang telah mereka lakukan secara mendekatkan diri kepada Allah.

3. Penulis melihat bahwa al-awlawiyyat terhadap jalan kemudahan ini sangat relevan dengan tuntunan syariat Islam dalam pemikiran alQaradhawi. Kemudahan yang dimaksudkan disini adalah:

Pertama, memberikan pemahaman yang mudah terhadap kebutuhan pengetahuan agama, merupakan kewajiban ulama Islam melapangkan jalan untuk membuat agama Islam ini mudah untuk difahami dan diamalkan, terlebih pada hal-hal yang terkait dengan masalah fikih.

Kedua, memberikan kemudahan untuk dapat diaplikasikan dengan baik. Hal ini dilakukan dengan memberikan kemudahan dalam mengambil pendapat yang mudah untuk diamalkan. ${ }^{14}$

Adapun dasar pemberian kemudahan itu adalah al-Qur'an, sebagaimana firman-Nya:

${ }^{13}$ Ibid., 89

${ }^{14}$ Talimah, Manhaj fikih, 82-85 


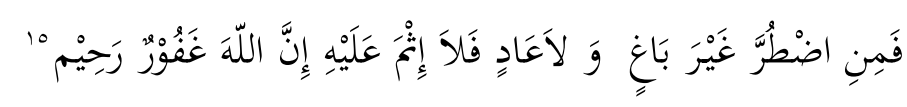

"Maka barang siapa dalam keadaan terpaksa, sedang ia tidak menginginkannya dan tidak pula melampaui batas, maka tidak dosa baginya. Sesungguhnya Allah Maha Pengampun lagi maha Penyayang".

\section{Al-Awlawiyyat terhadap amal}

Baik al-Qur'an maupun al-Hadits telah menjelaskan bahwa amal perbuatan yang terbaik menurut konsepsi syariat adalah perbuatan yang dilakukan secara konsisten. Di dalam al-Qur'andan al-Hadits terdapat istilah lebih utama (afdal) dan lebih dicintai (ahabb). Artinya, bahwa bagi para pelaku amal hendaknya senantiasa menekuni dan menjalankan secara terus menerus.

Dalam hal ini, al-Qardhawi memberikan komentar bahwa sebenarnya seseorang cukup melaksanakan suatu amalan yang jumlahnya sedikit, akan tetapi dilakukan secara rutin, sehingga akan muncul ketaatan yang terus menerus dan keberkahannya yang banyak. Berbeda dengan mengerjakan amal yang banyak, berat, namun dilakukan hanya sesekali saja. Amal yang sedikit, namun dilakukan secara terus menerus akan dapat berkembang, sehingga melebihi yang banyak tapi terputus hanya dalam beberapa waktu saja. ${ }^{16}$

Selain itu, figh al-awlawiyyat juga memprioritaskan amalan yang lebih banyak manfaatnya. Semakin besar manfaatnya bagi orang lain, maka semakin besar pula keutamaanya. Oleh karena itu, amalan jihad lebih utama dari pada amalan ibadah haji, sebab manfaat ibadah haji hanya untuk pelakunya, sedangkan amalan jihad bermanfaat untuk umat manusia. ${ }^{17}$ Demikianlah bahwa setiap amal bergantung pada sejauh mana dia mendatangkan kebaikan dan manfaatnya bagi masyarakat.

${ }^{15}$ Al-Qur'an, 2: 173.

${ }^{16}$ Ibid, 106.

${ }^{17}$ Terkait dengan masalah ini, al-Qardhawi menjelaskan bahwa jihad dijalan Allah lebih utama disisi Allah dari pada tekun beribadah. Ia mengutip sebuah ayat al-Qur'an surat al-Taubah ayat 19-20 : 
Terdapat pula pada al-awlawiyyat terhadap amal dan perbuatan psikis yang lebih diutamakan dari amal dan perbuatan fisik. Menurut alQardhawi ada beberapa faktor mengapa amal psikis harus lebih didahulukan dari amal fisik. ${ }^{18}$

Pertama, bahwa segala amal perbuatan fisik tidak akan diterima oleh Allah, tanpa didukung dengan hati dan dorongan batin, yang merupakan dasar diterimanya suatu amal, yaitu niat. Niat yang dimaksudkan adalah niat yang ikhlas, terlepas dari kecenderungan-kecenderungan pribadi dan keduniaan, sebab Allah tidak akan menerima suatu amal kecuali bila amal tersebut ikhlas karena-Nya.

Kedua, bahwa hati merupakan hakikat manusia, ia juga sebagai pusat kebaikan atau kerusakan. Selain itu, Nabi Muhammad Saw juga menjelaskan bahwa hati merupakan sasaran pandangan Allah. Sedangkan amal manusia merupakan cerminan dari kondisi hatinya. Nabi Saw dalam salah satu hadits menyebutkan:

$$
\text { الله لا ينظر إلى صوركم و أموالكم و لكن ينظر إلى قلوبكم و أعمالكم. }
$$

"Dari Abu Hurayrah r.a. berkata, Rasulullah Saw. bersabda: Sesungguhnya Allah tidak melihat bentuk dan hartamu, tetapi Ia melihat pada hati dan perbuatanmu".

Al-Qardhawi berpendapat bahwa sebagian di antara kita bersemangat dan sangat ketat dalam menkonsumsi makanan di Eropa dan Amerika.

“Apakah (orang-orang) yang memberikan minuman kepada orang-orang yang mengerjakan haji dan mengurus Masjidil Haram, kamu samakan dengan orang-orang yang beriman kepada Allah dan hari kemudian serta berjihad dijalan Allah? Mereka tidak sama disisi Allah, dan Allah tidak memberikan petunjuk kepada kaum yang zalim. Orang-orang yang beriman dan berhijrah serta berjihad dijalan Allah dengan harta benda dan diri mereka, adalah lebih tinggi derajatnya disisi Allah, dan itulah orang-orang yang mendapat kemenangan."

Al-Qardhawi, Fi Fiqh al-Awlaweiyyat, 107.

${ }^{18}$ Ibid, 115.

${ }^{19}$ Muslim, Sahih, 442 
Bersungguh-sungguh dalam mengadakan penelitian tentang kemungkinan adanya makanan yang mengandung babi atau minyaknya, tetapi mereka tidak lagi perduli dengan seseorang yang berkali-kali memakan daging saudaranya yang sudah menjadi bangkai, yaitu dengan melakukan tuduhan-tuduhan terhadap orang lain, baik dalam bentuk ghibah maupun fitnah, serta meyakini isu dan gosip yang berkembang dan kemudian menyebarluaskannya. ${ }^{20}$

5. Al-Awlawiyyat terhadap perintah Allah

Hal yang seharusnya mendapat perhatian pertama dalam perintah adalah mendahulukan yang ushul (pokok) dari pada yang furu' (cabang). Akidah adalah pokok, sedangkan syariat adalah cabangnya. Iman adalah pokok dan amal adalah cabangnya. Iman yang benar harus membuahkan amal yang baik, dan atas dasar kekuatan dan kedalaman iman, maka amalamal itu ada, baik itu dengan mengerjakan perintah atau menjauhkan diri dari larangan.

Adapun terkait dengan keutamaan ibadah bagi individu, ulama beragam pendapat tentang masalah ini. Dalam hal ini Ibn al-Qayyim menyatakan bahwa keutamaan ibadah sangat berbeda antara seorang dengan yang lain, antara satu waktu dengan waktu yang lain, antara satu tempat dengan tempat yang lain, dan satu kondisi dengan kondisi yang lain. Menurutnya, ketika seseorang menyatakan iyyaaka na'budu, itu berarti baginya ibadah yang paling utama dan paling berhak untuk diprioritaskan terdapat empat pendapat. ${ }^{21}$

Pertama, bagi mereka ibadah yang paling utama adalah yang paling berat bagi diri dan jiwa. Alasannya, hal itu merupakan sesuatu yang paling jauh dari hawa nafsu dan penyembahan yang sesungguhnya. Alasan lain menurut mereka adalah bahwa perolehan pahala bergantung pada tingkat kesulitannya.

Kedua, bahwa ibadah yang paling utama adalah membebaskan diri dari segala urusan materi dan berlaku zuhud. Sebagian di antara mereka menganggap bahwa ibadah yang mereka lakukan merupakan tujuan akhir,

\footnotetext{
${ }^{20}$ Al-Qardhawi, Fi Fiqh al-Awlawiyyat, 118-120.

${ }^{21}$ Ibn Qayyim al-Jawziyah, Madarij al-Saalikiin, vol. 1 (Beirut: Dar al-Kutub al-
} 'Ilmiyyah, tt), 97-102. 
menurut mereka hal ini lebih utama dari tingkatan ilmu dan ibadah lainnya, dan meninggalkan kesenangan dunia merupakan tujuan dari setiap ibadah. Sebagian yang lain berpandangan ibadah itu merupakan sarana untuk mencapai tujuan ketenangan hati kepada Allah.

Ketiga, mereka berpendapat bahwa ibadah yang paling utama adalah yang manfaatnya lebih banyak. Menurut mereka membantu orang fakir, memberi kemaslahatan bagi orang lain adalah ibadah yang paling utama. Keempat, mereka mengatakan bahwa ibadah yang paling utama amal yang paling diridhai Allah dalam setiap waktu sesuai dengan waktu tertentu serta tugas-tugas tertentu yang diemban pelakunya. Maka ibadah yang utama pada saat shalat fardhu adalah bersiap-siap secara sempurna, cepatcepat melakukannnya di awal waktu, dan keluar menuju masjid, bila letak masjid jauh, maka hal itu lebih utama. Bergabung bersama dalam kebaikan lebih utama dari pada menyendiri dalam kebaikan, bila diketahui bahwa dengan bergabung dapat menghilangkan kejahatan yang akan dilakukan oleh sejumlah orang, maka bergabung pada saat itu lebih utama dari menyendiri (berkhalwat). ${ }^{22}$

Al-Qardhawi menyebutkan bentuk lebih riil yang sedang menggejala bagi kaum muslim saat ini adalah bahwa di tengah-tengah kita banyak terdapat kaum muslim yang menunaikan ibadah haji dan umrah hingga lima, sepuluh dan dua puluh kali. Sebagian ada yang menunaikan umrah setiap bulan, tiada segan-segan mereka mengeluarkan sejumlah uang untuk kegiatan ritual semacam itu. Sementara, masih banyak kaum muslim lainnya yang kehausan dan kelaparan, mengalami penindasan dan pembantaian. Para ulama menyatakan bahwa sesungguhnya hak-hak Allah dibangun atas dasar toleransi, sementara masih banyak kaum muslim lainnya yang kehausan dan kelaparan, serta mengalami penindasan dan pembantaian.

6. Al-Awlawiyyat terhadap larangan Allah

Al-Awlawiyyat terhadap sesuatu yang terlarang terdapat perbedaan tingkatan. Dalam skala prioritas terhadap sesuatu yang dilarang oleh Allah

${ }^{22}$ Al-Qardhawi, Awlawiyyat al-Harakah al-Islamiyah, 40 
adalah kekufuran, sementara tingkatan terendahnya adalah apa yang disebut dalam kajian ushul fiqh sebagai makruh tanzih.

Kekufuran dengan tidak mengakui ketuhanan, kenabian, kerasulan, dan pembalasan di akhirat. Agama bagi mereka adalah mitos, ketuhanan adalah legenda. Ini adalah kesesatan yang jauh, yang ditolak tegas oleh logika akal, logika fitrah, logika ilmu, logika alam dan logika sejarah, apalahi logika wahyu yang telah memberikan bukti-bukti andal tentang kepastiannya.

Dalam hal kesyirikan, juga terdapat tingkatan. Tingkatan terbesarnya adalah menjadikan sekutu bagi Allah. Mengutip pendapat Ibn al-Qayyim kembali, menyebutkan bahwa tingkatan syirik yang terkecilnya adalah riya', berpura-pura di hadapan manusia. ${ }^{23}$

\section{Penutup}

Pada bagian akhir kajian ini, penulis ingin memberikan beberapa kesimpulan dari pembahasan penelitian ini, antara lain:

1. Ada tiga pendekatan yang sudah dikembangkan oleh ulama dalam melakukan istimbat hukum, yaitu pendekatan kaidah bahasa, pendekatan pada pemahaman maqasid al-syariah, dan pendekatan dengan metode tarjih. Secara khusus al-Qardhawi mencoba menawarkan satu bentuk metode dengan dua bentuk ijtihad kontekstual. Pertama, ijtihad intiqa'i yang berarti memilih satu pendapat dari beberapa pendapat yang terkuat. Dan kedua, ijtihad insya'i yang berarti mengambil kesimpulan hukum baru dari suatu persoalan yang belum pernah dikemukakan oleh ulama terdahulu.

2. Di kalangan ulama, baik klasik maupun kontemporer, banyak yang menaruh perhatian terhadap fikih al-awlawiyyat. Umumnya mereka memprihatinkan kondisi masyarakat muslim yang tidak memperhatikan skala prioritas dalam syari'at.

3. Pendalaman tentang agama yang terpenting adalah pengetahuan dan pemahaman akan nilai dan tingkatan suatu amal sesuai koridor syariat. Syariat Islam meletakkan nilai-nilai tertentu bagi tiap-tiap perbuatan

${ }^{23}$ Al-Jawziyyah, Madarij, 364-369. 
sesuai dengan pengaruhnya dalam jiwa dan kehidupan. Selain itu syariat Islam juga menetapkan tingkatan tertentu terhadap hal-hal yang dilarang sesuai dengan tingkat kerugian dan keburukannya.

\section{DAFTAR PUSTAKA}

Al-Qardhawi. 1995. al-Imam al-Ghazali bayna Mādihīhi wa Naqidihi. Kairo: Dar al-wafā' .

Al-Qardhawi. Awlawiyyat al-Harakah al-Islamiyyah.

Ensiklopedi Islam. 1993. Jakarta: Ichtiar Baru Van Hoeve.

Ibn Qayyim al-Jawziyah. Tt. Madarij al-Saalikiin. Vol. 1 Beirut: Dar al-Kutub al-'Ilmiyyah.

Sayyid Qutb. 1998. fi Dzilal al-Qur'an. Kairo: Dar al-Syuruq.

Schacht, Joseph. 1971. An Introduction to Islamic Law. London: Oxford at The Clarendom Press.

Zaidan, Abd. Karim. 1986. Majmu'at Buhuts Fiqhiyyah. Baghdad: Maktabah al-Quds. 